\title{
UMA NARRATIVIDADE EM MUTAÇÃO: RECEPÇÃO E PRODUÇÃO DE CAUSA AMANTE DE MARIA GABRIELA LLANSOL ${ }^{1}$
}

Maria Lúcia Wiltshire de Oliveira Recebido 05, mar. 2010 / Aprovado 26, abr. 2010

\section{Resumo}

Causa Amante (1984) permite observar a dimensão mutante da textualidade llansoliana, nascida em cadernos manuscritos, consolidada em dossiês datiloscritos e editada a duras penas em livros. Após o levantamento da recepção crítica às duas edições do texto, examinamos os bastidores da sua produção, considerando alguns tópicos de reflexão recorrentes nesta escrita: pesquisa do material romanesco, uso da metalinguagem, criação das figuras, dificuldades de edição dos livros. Afastada do padrão narrativo tradicional, a obra se compõe e se recompõe constantemente em processo que serve de paradigma à textualidade assinada por Maria Gabriela Llansol.

Palavras-chave: Recepção. Produção. Textualidade llansoliana

\footnotetext{
1 Este trabalho representa o resultado de parte da pesquisa realizada sob os auspícios da CAPES junto à Universidade Nova de Lisboa, de novembro de 2009 a fevereiro de 2010, no acervo do Espaço Llansol em Portugal.
} 


\section{Para João Barrento e Maria Etelvina Santos}

Há três coisas que metem medo: (...) A primeira é a mutação.

(...) O mutante é o fora-de-série, que traz a série consigo.

(Llansol, Livro das Comunidades, 1977)

\section{Parte I - Recepção}

2 As obras publicadas de Maria Gabriela Llansol, considerando as primeiras edições, são as seguintes: Os Pregos na Erva (1962); Depois de Os pregos na Erva (1973); O Livro das Comunidades (1977), A Restante Vida (1983) e Na Casa de Julho e Agosto (1984), estes últimos integrando a primeira trilogia, Geografia de Rebeldes; Causa Amante (1984), Contos do Mal Errante (1986) e Da Sebe ao Ser (1988), integrando a segunda trilogia, O Litoral do Mundo; Amar um Cão (1990); O Raio sobre o Lápis (1990); Um Beijo Dado Mais Tarde (1990); Hölder, de Hölderlin (2000); Lisboaleipzig I. $\mathrm{O}$ encontro inesperado do diverso (1994); Lisboaleipzig II. O ensaio de música (1994); Ardente Texto Joshua (1999); Onde Vais, Drama-Poesia? (2000); Cantileno (2000); Parasceve. Puzzles e Ironias (2001); O Senhor de Herbais. Breves ensaios literários sobre a reprodução estética do mundo, e suas tentações (2002); O Começo de Um Livro é Precioso (2003); O Jogo da Liberdade da Alma (2003); Amigo e Amiga. Curso de silêncio de 2004 (2006); Diários: Um Falcão no Punho. Diário I (1985); Finita. Diário II (2005); Inquérito às Quatro Confidências. Diário III (1996). Durante a sua vida (1931-2008) Llansol publicou ainda textos avulsos e traduções de autores franceses.

3 Foucault trata da "posição transdiscursiva" como uma autoria que se consagra para além da obra individual, fundando paradigmas que permanecem na história da cultura. Cf. O que é um autor? 1992, p.57-67.
A narrativa de Maria Gabriela Llansol sobrevém como mutação no quadro do romance português contemporâneo. Segundo Maria Alzira Seixo, caminha para a "ficção poética" (SEIXO, 1986b, p. 26), a exemplo do que fizeram Raul Brandão em Húmus e Carlos de Oliveira em Finisterra, nela se dando o "predomínio narrativo de actuação indicial" em que a categoria lukacsiana da "aventura" se aplica a todos os elementos romanescos: herói, narrador, personagens, espaço ("de definição parcelar e sujeito a ser animizado") e tempo ("de constante alteração, seja o da história, seja o tempo de uma intervenção cultural [...]: doutrinas, religiões, heresias"). Assim "a ficção auto-referenciase pela constante mutação dos seus planos [...]" (SEIXO, 1986b, p. 26) que passa pelo "corp'à screver":
Alteridade pura, este texto é exatamente o 'outro' de quem ultrapassou o espelho e do lado de lá o recorda, ou acorda. Centrais aqui a história, o texto e o ser. Ligados numa metafí- sica que pretende que a escrita seja a própria expressão física das coisas. Envolvente poesia, reflexiva prosa, dramaturgia de textos (e de tempos e de vozes). (SEIXO, 1986b, p. 27)

Nesta nova maneira de conceber a narratividade desde $O$ Livro das Comunidades até a última publicação em vida, ${ }^{2}$ Llansol aposta numa textualidade que ultrapassa a dicotomia formaconteúdo, firmando um pacto de fidelidade quanto à verdade sobre si e sobre o mundo cujas matrizes estão, não apenas nos nomes portugueses citados acima, mas em autores transdiscur$\operatorname{sivos}^{3}$ que reviraram os pressupostos da representação literária, tais como Mallarmé e Rimbaud, e os artistas das vanguardas modernistas - futuristas, dadaístas e surrealistas.

Seixo mostra como Llansol faz um atentado violento aos protocolos romanescos de leitura pela "coexistência de registros discursivos: romanesco, lírico e reflexivo [...]" (SEIXO, 1986c, p. 29), além da "mancha de prosa" e do padrão de versículos (SEIXO, 1986c, p. 30). A narrativa se faz por pequenos núcleos independentes que se alojam numa sintagmática total do livro em que a frase é um sintagma hesitante, permeada de paradas, encadeadas como litania, "de teor profético e encantatório" (SEIXO, 1986c, p. 30). A aventura do herói é atípica, pontilhada de elipses, de que se contam apenas os episódios de ressonância lírica, já que os fatos estão contados nos livros de História ou outros. Ao destacar a ausência de espelhamento mimético que é substituído 
pela "continuidade orgânica entre o real e as palavras, entre o mundo e a escrita" (SEIXO, 1986c, p. 33), a crítica portuguesa emite o seu julgamento de valor sobre Causa Amante:

[...] penso que esta obra é privilegiada para o pensamento do literário atual - desde que se entenda que a compreensão da literatura passa por definições e por classificações que, no entanto, serão constantemente ultrapassadas pelos textos, os quais, em última análise, têm sempre razão. (SEIXO, 1986c, p. 33)

Por esta e outras razões escolhemos Causa Amante para observar a dimensão mutante de uma escrita que abdica dos pressupostos da narrativa e se aproxima da poesia, mas ultrapassa qualquer dicotomia ou mesclagem que possa circunscrevê-la a "ficção lírica", prosa poética ou poema em prosa. Cremos que uma das formas de entender a escrita llansoliana é a do exame do processo de sua produção tal como registrada nos inúmeros Cadernos manuscritos da autora, transposta depois para dossiês e outros datiloscritos que seguiam para a edição final. Esta é a nossa proposta quanto a Causa Amante, mas antes disso, e para melhor ilustrar a surpresa e o estranhamento causados nos críticos e leitores de primeira hora, começamos por uma abordagem da recepção deste livro até a data.

\section{Os primeiros amantes}

O acervo bibliográfico sobre Causa Amante não é extenso em Portugal ${ }^{4}$ e inexistente no Brasil. ${ }^{5}$ No ano do lançamento (1984),

4 A pesquisa em Portugal abrangeu a Biblioteca Nacional em Lisboa, as bibliotecas da Universidade Nova de Lisboa, da Faculdade de Letras da Universidade de Lisboa - Clássica e da Faculdade de Letras da Universidade de Coimbra, assim como o acervo do Espaço Llansol, casa em Sintra que abriga o espólio completo da autora e onde viveu nos últimos anos.

5 A pesquisa no Brasil limitou-se ao exame da produção relacionada às especialistas Lúcia Castelo Branco e Maria de Lourdes Soares, ligadas aos dois pólos atuais de investigação da obra de Llansol, respectivamente em Belo Horizonte (UFMG) e no Rio de Janeiro (UFRJ).

6 Diário de Lisboa, 23 Fev. 84; Espinho Vareiro, Mar. 84; Vária, 28 Fev. 84; e Jornal de Letras, 10 Abr. 84. registramos quatorze referências das quais são relevantes as de Eduardo Prado Coelho, Regina Loure, Paula Morão, Teresa Joaquim e Maria Alzira Seixo. As demais são notas elogiosas e breves, a metade anônima (quatro) ${ }^{6}$ e as restantes assinadas por Eduardo Prado Coelho (três) e António Colaço. A primeira e única polêmica surge com a resenha de Miguel Esteves Cardoso, respondida com farpas por Eduardo Prado Coelho. Dois anos depois, por ocasião da reedição do romance, registram-se ainda dois outros artigos de Maria Alzira Seixo e o Posfácio de Augusto Joaquim, totalizando até a data dezessete referências bibliográficas, entre as quais não se inclui nenhuma dissertação ou tese.

Na recepção inicial, deparamo-nos com a boa acolhida de Eduardo Prado Coelho que, numa nota curta de fevereiro de 1984, vai direto à essência do texto, entendendo-o não "como uma ficção, antes como um vazio de ficção que se retrai, e [que] nesse retraimento nos atrai para a espessura de uma escrita que nos inicia em esquecidos rituais" (COELHO, fev.1984). No mês seguinte, o crítico volta a recomendar o "livro de que ninguém fala, mas de que muitos gostam" (COELHO, mar.1984), apontando provavelmente para o artigo de Regina Loure, publicado na mesma edição do jornal, em que a articulista situa o desconcerto 
que a obra provoca no leitor: "Este é um livro que não basta ler, porque lê-lo dá vontade de o habitar. Mas habitar o quê? onde?" (LOURE, mar.1984). Sob o título "Entre tudo e nada", retirado da progressão dos "passos" da primeira parte do romance, o artigo enfatiza a incerteza que rege Causa Amante, litoral ou margem flutuante movido por um "centro móvel" que refaz histórias não registradas para onde se deslocam as figuras, e onde habita igualmente a própria obra da autora, afastada para as margens da literatura portuguesa: "Há um esboço de assunto que ora é o centro do livro, ora é uma das suas margens, espécie de eixo em torno do qual a 'acção` se desenrola" (LOURE, mar.1984). Além do princípio místico ou religioso (re-ligare) que pontua as obras de Llansol, a resenhista ressalta a equivalência ontológica entre os diferentes elementos da natureza - homem, animal, planta, rocha - numa tentativa persistente de escutar o mundo, trazendo-lhe à memória os livros de Clarice Lispector. Antes de ser romance ou mesmo ficção, Causa Amante é para ela "o encontro inesperado do diverso" (LLANSOL, 1984, p. 18).

Como antecipamos, a primeira resistência ao livro surge em abril, na nota de Miguel Esteves Cardoso que a princípio elogia a capa, coisa de somenos importância ("refrescantemente sóbria e impressionantemente inovadora"), para compensar os pequenos golpes ao estilo da autora ("escreve bem, às vezes muito bem e só aqui e ali menos mal") e, sobretudo, deplorar o caráter desestruturado da obra que "poderia ter sido um livro bonito" (CARDOSO, abr.1984). Em resposta, Eduardo Prado Coelho volta a recomendar o livro, orientando o leitor a não cometer "o desatino de supor que se trata de um 'romance' " nem muito menos ter "o mau gosto de insinuar que este livro até podia ser 'bonito' - isto é", não fazer "o que fez Miguel Esteves Cardoso em sua anacrônica avaliação" (COELHO, abr.1984). Isto prova a originalidade controvertida do lançamento e explica em parte porque não se enquadra na categoria "obra premiável", tal como se expressa Eduardo Prado Coelho em setembro, ao comentar o Prêmio Novela e Romance daquele ano. ${ }^{7}$

Em maio de 1984 aparece a recensão de Paula Morão que reproduz a capa do livro e ocupa cinco colunas da Coluna "Livros" do Expresso (Revista), tendo como título "Um animal chamado escrita" (MORÃO, mai.1984), extraído da epígrafe que é uma citação do livro. A resenha ressalta a "escrita multímoda" de Llansol feita de "uma multiplicidade de registros" literários (diarismo, memorialismo, lirismo, reconstituição histórica e epistolografia) e de vozes narrativas a partir de uma "narradora-matriz" que, "fazendo-se e desfazendo-se, constitui a figura

7 Comentário publicado na Secção Opções do Jornal de Letras e Artes de 3 de setembro de 1984. central de que saem e a que regressam todas as outras", estratégias que permitem compreender a ciclicidade dos elementos dos seus livros, que se iluminam reciprocamente. A resenha destaca ainda alguns elementos pontuais da obra, como o diálogo com 
a pintura de Rubens, o retorno do "pobre" de A restante vida, a função das beguinas "de construir o 'nomè e as 'cosmogonias' e de transformar um 'ser vivo' num 'ser escrito", trabalho já antecipado em $O$ Livro das Comunidades.

No mesmo mês, a resenha de Teresa Joaquim (cunhada da autora), intitulada "Causa Amante, a outra face", ocupa seis colunas do Diário de Notícias e começa por ressaltar o caráter metamorfoseante das figuras, que são mais do que a princípio se apresentam, assinalando a dificuldade da leitura que impõe um descentramento em relação à cultura, como já havia notado Regina Loure. Insiste na tópica do bom e mau encontro que rege a ficção de Llansol para exprimir a horizontalidade de todos os elementos na Natureza, destacando o papel misericordioso de Coração de Urso que se associa ao pensamento de Rilke. Com muitas citações, o texto não oferece uma orientação didática aos leitores, mas, em compensação, deixa claro que o livro propõe "a arte de realizar os encontros", inscrevendo-os na continuidade de várias culturas e na "desritmada penetração de épocas" (JOAQUIM, 1984), em que os seres têm a chance de uma nova vida e um lugar onde se abrigar.

Encerrando as referências de 1984, a nota de António Colaço no Diário Popular, em outubro, se insere numa reportagem sobre a Bélgica na coluna "Um país onde apetece viver" ocasião em que, a propósito da "beguinaria, espécie de convento fundado pela Condessa de Flandres, Margarida de Constantinopla" (COLAÇO, 1984), contempla a edificação envolta por uma cerca e a associa à passagem do livro Causa Amante em que Llansol evoca a casa das beguinas em Brabante.

Em janeiro de 1985, aparece a primeira recensão crítica em revista especializada, assinada por Maria Alzira Seixo, ${ }^{8} \mathrm{em}$ que o desenvolvimento das ideias é ainda aproximativo e menos elucidativo se a comparamos com os dois outros artigos publicados pela autora no volume de 1986. De tom elogioso, predomina na resenha a hesitação diante da peculiar narrativa llansoliana que não se enquadra em nenhum padrão, apesar de manter uma homogeneidade sintática e semântica que comunica e emociona, sobretudo pela "paisagem das ficções" e pelo "movimento da escrita". Há uma preocupação em reconhecer afinidades do texto com "a prosa poética, com o ritmo dos salmos, com a pro-

8 Publicada inicialmente na Revista Colóquio /Letras, n 83 (Janeiro de 1985), pp. 99-100, a recensão foi inserida na Parte III do volume da autora, A Palavra do Romance; Ensaio de Genologia e Análise, Lisboa, Livros Horizonte, 1986, com o título "Causa Amante de Maria Gabriela Llansol". clamação profética, com a ficcionalidade pura - sem no entanto se resolver pela integração no poema em prosa ou no romance de marca tradicional." (SEIXO, 1986a, p. 231). Como marca da própria textualidade, a presença da heresia é referida como "caminho de liberdade, signo da mutação do ser no mundo" (SEIXO, 1986a, p. 232). Também aqui aparece a menção - quase obrigatória - ao misticismo em Llansol, visto como "ancoragem da relação entre a religiosidade anímica e o quotidiano concreto, 
entre a perda mística e o encontro da matéria textual" (SEIXO, 1986a, p. 230).

No outro artigo da sua coletânea, Seixo faz comparações entre Llansol, Saramago e Mário Cláudio, destacando singularidades e diferenças no tocante à alteridade e à autorreferencialidade que em Llansol se manifesta, quanto ao primeiro aspecto, como o próprio texto, "o 'outro` de quem ultrapassou o espelho e do lado de lá o recorda, ou acorda" (SEIXO, 1986b, p. 27) e, quanto ao segundo aspecto, na forma da "mutação dos seus planos, não entendida como busca ou incerteza mas antes como respiração larga, tensa ou distensa, de um enorme desejo de escrever" (SEIXO, 1996b, p. 26) sendo a escrita "a própria expressão física das coisas" (SEIXO, 1986b, p. 27). No artigo seguinte, Seixo dedica-se, mais uma vez, a se interrogar a respeito do surpreendente "sintagma totalizante" (SEIXO, 1986c, p. 30) que mantém coesa a escrita de Causa Amante, apesar da "floresta de registos discursivos" (SEIXO, 1986c, p. 33) que lembra o texto de Nerval. Volta a falar em "ficção lírica", advertindo, através de citação da autora - "uma ficção não pode ser simples, é o encontro inesperado do diverso" - que tal "frase é uma 'mise en abymè discursiva da sua ficção em termos de processo da aventura e da desarticulação narrativa" (SEIXO, 1986c, p. 29). Impedida de alcançar uma palavra definitiva sobre a obra, acaba por reafirmar a sabedoria dos textos quando se trata de renovar o arsenal teórico para a compreensão da literatura contemporânea.

Encerrando a recepção de Causa Amante, chegamos ao ensaio de Augusto Joaquim, marido e primeiro crítico de Maria Gabriela Llansol, publicado como Posfácio da $2^{\mathrm{a}}$ edição do livro. Na sua análise o autor adota uma teoria não-estruturalista, baseada na concepção orgânica, oposta aos modelos tradicionais, por meio da qual relaciona todos os elementos em rede rizomática e os interpreta como adiamento da entropia das formas. Trata-se de uma abordagem singular, baseada na Física (e por isso custosa de entender), que utiliza operadores que dão conta da dinâmica energética que circula no texto, através de trocas e sobreposições, deslocações e mutações entre as figuras, os seres criados, a paisagem e o tempo. Este "primeiro leitor a desejar que o texto se aproximasse do humano" (JOAQUIM, 1996, p. 169) recorta dois fragmentos do livro - a interpelação de Dom Sebastião e o Passo I - e neles aplica uma microanálise que serve de paradigma para outras cenas e outros livros de Llansol. O estudo crítico tem ainda um valor testemunhal, pois situa sua convivência com Llansol e a percepção da sua escrita como fruto de desejo e cálculo, para além de qualquer casualismo dadaísta.

Para a compreensão do texto llansoliano, Augusto invoca a força da oralidade (experiências de leitura em voz alta), conectando-a aos daïmons silentes e sonoros dos gregos antigos, divindades ligadas à natureza e aos afetos humanos que na sua 
linguagem crítica são uma Energia Livre de Origem Vibratogênea (ELOV). Diz que o novo e o desconhecido em Llansol é um visitante que não se impõe, mas se insinua, eliminando a solidão; e que neste encontro "não será com velocidade pensante que se continuará o diálogo" (JOAQUIM, 1996, p. 174), vivência que o levou ao recolhimento e à transformação do seu olhar sobre o mundo. Como um daïmon, o livro Causa Amante também é formado por segmentos doadores de ELOV, um dispositivo ou engenho de natureza orgânica (ou grave), à exceção de certos fragmentos potenciométricos ou agudos que obedeceriam ao modelo ideológico que "articula de maneira rígida e indissolúvel o valor e o afecto" (JOAQUIM, 1996, p. 181-2). O procedimento deixa ver formas de captação de dispersão que provam que "o rei [Dom Sebastião] não estava a ser insensato" ao se lançar em Alcácer Quibir, e "que o intento da Causa Amante é libertar o rei do destino inexorável que o espera, encontrar-lhe outro dispositivo em que possa ser um pensante sensível" (JOAQUIM, 1996, p. 184), o que efetivamente acontece com a sua transformação em dom arbusto.

A análise deste trecho serve de contraponto aos demais, em especial ao do Passo I, de natureza orgânica, onde vigora uma "abertura mútua" entre os componentes da cena que geram uma intensificação energética neguentrópica. Aqui o texto desliza, desloca-se num movimento em que as formas de captação não têm nenhuma rigidez, retroalimentando-se recíproca e indefinidamente em pontos de "coincidência das similitudes" (JOAQUIM, 1996, p. 191), o que nos reenvia ao mundo das semelhanças em que ainda vivia Dom Quixote. Tal poética de captação por deslocação e abertura mútua seria chamada por Llansol de "as artes das beguinas" que estão constantemente contrapondo-se ao desperdício de energia em sua dimensão "migratória".

Apesar de posteriores à $1^{\text {a }}$ edição, as análises de Augusto Joaquim e de Maria Alzira Seixo são incontornáveis para os estudiosos do texto, ainda que se deva render tributo aos comentários dos "amantes" de primeira hora que corajosamente abriram voz em favor da estranha e surpreendente forma de Causa Amante.

\section{Parte II - Produção}

Com esta obra Maria Gabriela Llansol iniciou uma nova trilogia, não mais de rebeldes, ${ }^{9}$ mas de desviantes que habitam O Litoral do Mundo I, num amplo afresco sobre a história de Portugal ao qual se agregam Contos do Mal Errante (1986) e Da Sebe ao Ser (1988). Ainda que escrito em terras estrangeiras (Lovaina, Jodoigne e Herbais, na Bélgica), a paisagem predominante por

9 Segundo Augusto Joaquim, rebelde significa ir "contra a ordem estabelecida da entropia." (JOAQUIM, 1996, p. 184) onde circulam as figuras é Portugal: Cabo Espichel, Convento dos Capuchos de Sintra, Igreja de Santa Engrácia, Terreiro do Paço, Calçada da Graça, Calçada de Santana. O texto foi produzido em 
10 A referência aos Cadernos se fará sempre à série 1 , seguida do número do Caderno (06 a 10), acompanhado do número da página, também de forma abreviada - Cad.1.06, p. - conforme o padrão usado no Espaço Llansol, em Sintra, Portugal, onde se realizam pesquisas subsidiadas pela Fundação Calouste Gulbenkian voltadas para o espólio da autora sob a responsabilidade de João Barrento e Maria Etelvina dos Santos. Há duas séries de Cadernos já digitalizados (1 e 2), a primeira incluindo 76 cadernos manuscritos, dos quais $20 \%$ aproximadamente já dispõem de índice remissivo. Os cadernos oscilam mais ou menos entre 200 a 300 folhas manuscritas do tamanho A5 ou metade da A4.

11 Os hypomnemata são uma forma antiga de escrita entre diário e caderno de anotações estudada por Foucault como escrita de si em $\mathrm{O}$ que é um autor?, 1992. parte nos Cadernos da autora referentes ao período de janeiro de 1979 a setembro de 1980, já digitalizados e categorizados em índice remissivo. ${ }^{10}$ Llansol usou extensivamente essa espécie de hypomnemata ${ }^{11}$ para compor suas obras, cujos trechos ficcionais quase sempre sofrem alguma alteração ao serem transcritos para os dossiês e/ou livros.

Para a observação da escrita de Causa Amante interessounos a consulta aos Cadernos 1.06, 1.07, 1.08, 1.09 e 1.10, relativa ao período da produção do texto, bem como o Dossiê da obra, versão datiloscrita intermediária entre os cadernos e a edição publicada que não examinaremos neste trabalho. Dossiês e Cadernos são certamente objetos próprios de uma investigação de crítica textual e aguardam pesquisadores especializados. Para os estudiosos do literário, são elementos capazes de relevar os meandros da produção do texto e as vicissitudes da voz narrativa que, juntamente com as figuras, habitam as cenas da autoria e do "enredo" da obra.

É bom acentuar que não corremos atrás do eu autoral, por sabê-lo de antemão inalcançável em sua unicidade; tentamos no entanto nos aproximar da "plurivocidade" autoral de que fala Foucault, da "subjetividade do não-sujeito" referida por Barthes, da "voz narrativa" fantasmática intuída em Blanchot, do gesto do autor acenado por Agamben, da voz partilhada escutada por Jean-Luc Nancy, da individuação sem sujeito defendida por Deleuze e Parnet, enfim, do vazio que realiza e se retira incessantemente da escrita.

\section{Cadernos e nascimento do texto}

"Uma das maiores bênçãos da minha vida foi ter um caderno à mão." (Llansol, Cad.1.50, p. 11)

Falar de gênese implica uma visão totalizante que não se ajusta à concepção da escrita-devir que marca os textos da autora portuguesa. Gênese lembra a mão divina que criou o mundo de um jato só, enquanto o fiat humano, em especial o daquele que escreve, é muito menos autocontrolado e se filia, não a Deus, mas a seu antípoda, o errante Caim.

Onde nasce a escrita de Maria Gabriela Llansol? Certamente não chegaremos a um resultado palpável sobre este lugar porque um corp' a 'screver, apesar de ter um cérebro pensante, é muito mais do que "ele" sabe em razão da filogênese que se espraia rizomaticamente não só para o passado e o futuro, mas também para todas as direções do presente. Isto quer dizer que não há uma semente primeira onde repousa e germina a linguagem e o pensamento, mas ao contrário, para além de um inconsciente individual ou coletivo, a mente humana se cria e se alimenta de associações múltiplas vindas de tudo à sua volta, produzindo registros em permanente fluxo através de encontros 
e capturas, apropriações e reterritorializações, como nos ensina Deleuze. Sabemos que a escrita de Llansol nasce e se transforma nos cadernos e nos dossiês, mas esta sucessão aparentemente causal dos seus rastros - os documentos deixados - não representa tão só a história de uma escrita mas escritas que se diferenciam em momentos distintos. Se o livro editado é a forma final pela qual a sociedade literária consagra uma escrita e se não há como partilhar a escrita senão desta forma, isto não invalida as escritas anteriores. Não só porque deixam de ser consideradas como a origem impura de um produto final acabado, mas sobretudo porque revelam o trabalho simultaneamente intencional e casual, de cálculo e de delírio, que rege o braço que escreve. $\mathrm{O}$ fascínio da crítica textual decorre em parte deste olhar para as alteridades da escrita, como bifurcações que se abrem e que se abandonam no instante da produção, igualmente importantes para o corpo que os escreve, mas necessariamente rejeitadas para que o livro alcance uma edição final. É a melhor forma? Não podemos responder a esta questão, nem nos interessa fazêlo. Fiquemos por ora com a observação inspirada em Yi King, livro da tessitura das transformações, muito consultado pela autora:

Eis porque me apaixona a trama transformativa da minha escrita. Diria nossa escrita, referindo-me a outros escritores, porque tudo o que se transforma, e transforma, o tomo como nosso. [...] Quando eu olhava os tecidos com tanta admiração e desejo, não sabia por que". (Cad. 1.06, p. 271)

A riqueza própria dos Cadernos justificaria uma descrição e análise independentemente das obras que lá se esboçam. No entanto o nosso objetivo aos examiná-los é recolher passagens que direta ou indiretamente se relacionam com a produção do romance, sem nos determos muito nas passagens ficcionais que serão transferidas depois para o dossiê e para a edição final de Causa Amante, onde estão para serem lidas e interpretadas. Na comparação dos trechos produzidos nos Cadernos e o Dossiê, há certamente muitas alterações sob a forma de substituições e expurgos, cuja exposição não faz parte dos nossos propósitos neste artigo. Por ora apenas registramos alguns casos exemplares que mostram o exercício da autoria como um processo múltiplo e associativo que agencia relações, acontecimentos, objetos, leituras, enfim, uma infinidade de linhas de fuga impossíveis de serem mapeadas com precisão.

Sabemos que a criação de Causa Amante se conecta de alguma forma com a neve que cai sobre Jodoigne, no Brabante, região da Bélgica, em 5 de janeiro de 1979, quando Llansol se refere ao romance A Montanha Mágica (1924) de Thomas Mann e à necessidade de consultar uma Enciclopédia para saber quem ela é (a neve) "sob o ponto de vista físico" ("O que é para poder se tornar quem é") (Cad.1.06, p. 148). Sabemos que a primeira 
frase de Causa Amante faz referência a este ambiente: "estou coberta pelo nascimento de Ana de Peñalosa e a neve, que ia fundir-se, voltou a cair" (CA, 11). ${ }^{12} \mathrm{O}$ que não podemos saber é como a leitura de Mann (embora cientes de que a diegese do romance se passa num sanatório nos Alpes) e a neve que caía sobre Jodoigne se conectaram dando lugar a um terceiro que não é um nem outro mas um "entre ambos", dando razão a Augusto Joaquim quando fala de "captação por rede" e de uma "termodinâmica do sentido" nesta passagem por ele analisada (JOAQUIM, 1996, 188-9). Tentando entender este processo de transposição, a própria Llansol fala sobre a passagem "do nível do sonho" para o nível da composição do romance, "isto é, para um nível nebuloso penetrado por um esforço de decifração" (Cad.1,07, p. 55), constituindo aquilo que Augusto chama "entresser" e que faz surgir um outro desconhecido.

A autora confessa estar assustada diante do texto, "grande texto que já várias vezes [...] [a] atraiu com as suas inúmeras formas, tempos e destinos" (Cad.1.06, p.150), momento em que se delineia o primeiro título do romance que lhe promete muitas recompensas:

Trago o nascimento de Ana de Peñalosa dentro de mim, vai durar anos se eu puder escrever um livro que dure. Que o momento em que tal livro fora acabado, pense em mim, nos dias, e noites, incompletos em que o procurava com o pensamento de que só assim, saltar sobre a nossa morte, eu mais meus seres amados também finitos, me era possível. (Cad.1-06, 159) (negrito nosso)

Algum dia após esta reflexão surge a cena da neve no Caderno, que estava em gestação - "Estou coberta pelo nascimento [...] e a neve [...]" - (Cad.1.06, p.160, 9 de Janeiro) -, transposta depois para o Passo I-Aqui do romance (CA, 11); no final do mês (27 de janeiro) aparece a outra cena - "é hoje que verdadeiramente, o nascimento de Ana de Peñalosa, nasce (...)" (Cad.1.06, p.181) que se encontra no Passo II-É (CA,13-14). Isto demonstra que o nascimento do livro, então chamado "O nascimento de Ana de Penãlosa", só acontece após a narradora ter sido por ele coberta, ou seja, inseminada. O texto é um ser que deve amadurecer por si mesmo para vir à luz: "Outro dia, apenas com algumas páginas escritas, ele tinha-se apresentado para nascer; mas era apenas um início, um horizonte fechado. Não estavam determinados nem a perspectiva, nem o lugar." (CA, 13). Por isso a leitura de Llansol deve ser literal: quando ela diz "coberta", é exatamente "coberta" aquilo que quer dizer, e não uma metáfora abstrata

${ }_{12}$ Doravante as citações à Causa Amante se referem à segunda edição (1986), sob a forma abreviada CA seguida da(s) página(s). para idealizar a produção autoral. Só mais adiante ela introduz as aspas para confirmar o título do livro, ao mesmo tempo em que se subordina ao seu fluxo: "O nascimento de Ana de Peñalosa" começa a desenrolar-se com / nas palavras e eu vou com ele" (Cad.1,06, p.192), idéia que se repete meses depois (junho 
de 1979) quando compara a produção do livro a um fluxo em mancha poética:

faça o que fizer, esteja ocupada no que estiver ocupada, vejo-o
sempre
cair, refluir
como
uma
cascata. (Cad.1.07, p. 57)

Na posição de um observador externo, Llansol examina o seu próprio processo criativo feito de melancolia, vaguidade e captação auditiva, pelo qual os "seres nasceram pela voz", sendo "seus corpos secundários e insignificantes" (Cad.1,07, p. 170):

Neste período sempre por detrás das palavras ainda não pronunciadas, está o nascimento de Ana de Peñalosa, sem ser vago apenas não todo presente. Não vindo aos olhos, antes de vir ao ouvido. Parece-me que é com os olhos que ouço sempre primeiro as palavras, com seu traço, som, melancolia (...) (Cad.1.06, p. 194-5)

A este trecho segue-se a preocupação em esboçar a intriga do livro, dele só recebendo "uma voz envolvente" (Cad.1.06, 198) a que se submete a ponto de saltar da paisagem do Cabo Espichel (parte I do livro - tempo histórico "presente") para o bairro de Alfama, em Lisboa, onde se situa a Igreja de Santa Engrácia (parte II do livro - século XVII), o que demonstra que a produção dos segmentos/fragmentos do livro não corresponde à ordem em que aparecem na edição final. ${ }^{13} \mathrm{O}$ tempo em Llansol é diferente, conforme dirá mais tarde: "Esta noite tive a percepção de que o tempo não era linear, o tempo deixou de ser linear; é uma estrela." (Cad.1.07, p. 50).

\section{Escrita e pesquisa}

Os cadernos relativos à produção de Causa Amante apresentam tópicos recorrentes que expressam preocupações e, por vezes, obsessões da função autoral quanto à genealogia e destinação da escrita, às limitações do autor, aos influxos aceitos e recusados, às vicissitudes próprias ao ato de compor uma

${ }^{13}$ Como exemplo citamos o trecho de CA, p. 37, iniciado por "Ainda bem (...) não é verossímil" que antecede a passagem da mesma página "ela está sentada debaixo (...)" (Cad.1.07, p. 268), embora tenha sido produzida depois (Cad.1.07, p. 272). obra. Ressalta deste conjunto o cuidado com a pesquisa como pré-condição da escrita: "Estudo para escrever. Porque é preciso estudar para escrever. A realidade não está na existência da superfície. A superfície precisa de ser colorida" (Cad. 1.47, p. 9). As cenas de Lisboa (parte II, Capítulo I - Movimento) se nutrem provavelmente de um "grosso volume" constantemente sob consulta (Cad.1.06, p.198), fornecendo a necessária precisão histórica e geográfica: "Necessito de ler passo a passo As pere- 
${ }^{14}$ Volume encontrável na biblioteca da autora - Rubens et son temps, Coleção Time Life Le mode des Arts, $4^{\mathrm{a}}$ ed. 1978 - cuja capa traz o retrato de Clara Serena. $\mathrm{Na}$ folha de rosto deste volume há duas anotações de Llansol: a primeira é: “31 Outubro 1979/Jodoigne" seguida da sua assinatura; a segunda faz referência à " 2 a leitura em Sintra/ 4/5/96". Estas anotações coincidem, respectivamente, com a produção original de Causa Amante e a publicação da $2^{\mathrm{a}}$ edição.

15 Para compor Levantado do chão José Saramago fez uma pesquisa preliminar junto aos camponeses do Ribatejo, para realizar O Memorial do Convento visitou Mafra e para escrever a História do Cerco de Lisboa releu passagens da História de Portugal. grinações em Lisboa [de Norberto de Araújo]" (Cad.1.06, p.286). Trata-se de um volume existente na biblioteca da casa na qual Llansol pesquisa "a exatidão de Lisboa" com o seu "sentimento de Lisboa" (Cad.1.06, p. 286), a ele voltando mais tarde (Fevereiro de 1980) para estudar as muralhas da cidade: "Lisboa, que dentro de si não cabia, 'cerca nova', extravasava dos Primitivos muros" [seguem-se as anotações tiradas do livro] (Cad.1.06, p. 257). Pensa em comprar a Enciclopédia Ilustrada de Costume e da Moda (em francês) pois "é uma primeira penetração na concisão de um mundo histórico em que desej [a] exercitar-[se] para ' $\mathrm{O}$ nascimento de Ana de Peñalosa" (Cad.1.06, p. 207, 12 de fevereiro de 1979) ao mesmo tempo em que levanta dados sobre a construção e a reconstrução da Igreja de Santa Engrácia, a profanação do sacrário e a queda da cúpula orbicular nos séculos XVI e XVII (Cad.1.06, p. 216). No dia seguinte todo este material passa a ser digerido por sua imaginação: "Hoje quase não trabalho. Leio como se percorresse água corrente; deito-me na cama e leio, vejo gravuras começo a imaginar, apoiada em fatos, a História". (Cad.1.06, p. 207).

Compondo a obra no estrangeiro, preocupa-se em realizar pesquisas no local da diegese quando surge a oportunidade de visitar a família em meados de 1979: "Preciso de preparar, pela antevisão, o que vou ver realmente em Portugal para trazer para o meu livro. Escrever aqui." (Cad.1.07, p.46).

A pesquisa não é uma atividade puramente racional e se guia também pela intuição: "Levanto-me disposta a abrir ao acaso as obras completas de São João da Cruz, a receber inteiramente o que vou ler" (Cad.1.08, p. 193). Por vezes o influxo se dá de modo não planejado, tal como em novembro de 1979 quando Llansol menciona a chegada pelo Correio do álbum sobre Rubens ${ }_{1}^{14}$ pintor flamengo sobre o qual comenta: "Antuérpia revive. Desejo contar a história das beguinas que, por momentos, está superior a meus próprios olhos" (Cad.1.07, p. 235). Se a princípio o interesse da encomenda foi motivado pelo Flandres onde habitam beguinas, ao folhear o álbum encontra informações sobre Clara Serena, a filha de Rubens, cuja imagem pintada pelo pai a impressionara desde criança quando ainda desconhecia o nome e a identidade da retratada. Acaba por fazer de Clara Serena uma figura de beguina no cabo Espichel, que lá chega junto com "os invasores, que podiam ser os perturbadores", mas que se inserem "de maneira serena", mesclando-se com "a rapariga que temia a impostura da língua", o duplo de Llansol que aparece em outras obras. Como se vê, a pesquisa não é um trabalho realizado $a$ priori, como já vimos acontecer com outros escritores, ${ }^{15}$ mas se faz no decurso da composição do livro fazendo-o incidir para um lado ou para outro.

Em meio às pesquisas iniciais, estão cenas da biografia de Ana de Peñalosa quando testemunha a profanação do sacrário da 
Igreja de Santa Engrácia onde o povo se comprime entre velhas paredes para ver o milagroso caso da morta incorruptível. No meio da multidão estão duas mulheres especiais com as quais Ana de Peñalosa se relaciona, mas cujo diálogo não passou para o livro: Alice (que secretamente espera curar-se com um milagre) e Engrácia (mulher analfabeta que dobra o nome da santa e da Igreja) são metamorfoses de pessoas relacionadas à vida real da autora, a saber, sua tia Alice (que sofreu uma operação da vista conforme está em Cad.1.06, p. 269), e Amélia, a antiga criada da família de grande importância no destino de Llansol. Os sonhos, sempre cuidadosamente anotados nos Cadernos, contribuem para a fatura da obra, tal como se dá no caso da cegueira, por duas vezes tema onírico: no primeiro sonho é a própria autora que precisa fazer uma operação nos olhos e no segundo ela se recusa a admitir que a sua gata Cisca esteja cega. Desta mesclagem entre sonho, realidade e imaginação, a autora do Caderno conclui: "Estabelecia um paralelo entre mim e entre as imaginadas Alice e Ana de Peñalosa. A cegueira de Alice protege Ana de Peñalosa dos ardores da iluminação, (...)". (Cad.1.07, p. 68).

A narração das relações entre a criada Amélia e a figura Engrácia, de tom sublime e grave, toca no ponto frágil da biografia: "Há horas longas e penetrantes que são horas de escrita diferida." (Cad.1.07, p. 41). Este diferimento banha o intróito da parte II de Causa Amante (em itálico, tal como o primeiro intróito que abre o livro), quando a narrativa de $3^{a}$ pessoa iniciada banalmente em minúscula - "estava deitada na sua própria cama (...)" - assume a voz em $1^{\text {a }}$ pessoa para lembrar fatos da infância envolvendo a criada:

ofereceram-me uma colher de prata [...]; foi um presente de Engrácia que, mesmo antes de eu ter nascido, já tinha importância na minha vida. [...] Engrácia [...] abria-me outra época para além da citadina, e rodeava-me de dimensões e de contos a percorrer. [...] A Engrácia chamava-lhe Mélito; agora, que aprendi a decompor as palavras compreendo que era "meu mito" que lhe chamava. (Cad.1.06, p.204-5; CA, 75 e 77)

Toda esta passagem de forte ressonância pessoal, transfigurada ficcionalmente no livro, será mais bem compreendida na entrevista a João Mendes, quando confessa que a criada, na verdade chamada Maria Amélia (daí a remissão ao diminutivo Mélito, que tudo e nada tem a ver com "meu mito"), fora persuadida pelos patrões a desfazer o embrião que concebera do filho solteiro da família, futuro pai da autora, para não conspurcar o caminho dos filhos legítimos, episódio que é o centro do livro Um beijo dado mais tarde (1990). No depoimento Llansol mostra que a fronteira entre a realidade e a invenção (alucinação) é precária e instabiliza igualmente os contornos da autobiografia e da ficção, sabedoria que herdou da criada analfabeta: 
Essa criada e a estória que lhe acontecera, a que só tive acesso por alusões, foi o primeiro sinal de que era necessário revolver o mundo. Escusam de me vir dizer que o mundo, a que o texto faz apelo, não existe, porque isso é o que eu sei, desde o princípio. Porque os que falam confundem, deliberadamente ou não, realidade e existência. Há muito real que não consegue existir, e há muitíssima existência que não tem (nem nunca teve) realidade alguma. A maior parte do que existe é miséria alucinada. Quando essa criada me contava estórias, e a criança, por ser muito inteligente, lhe respondia «mas, Amélia, isso não existe», ela dizia-lhe «menina, não diga que não existe, porque não sabe, procure onde está». (LLANSOL, Entrevista, 1995)

O esforço de composição do livro em curso é grande, "obra de esforço largo" (Cad.1.06, p. 211), que por vezes desanima a escrevente que não consegue "articular duradoura e especialmente a escrita" (Cad.1.06, p. 29), mas que paradoxalmente deixa um PS a revelar sua submissão à corrente do escrever: "Nunca escrevi um livro assim; nunca assim fui escrita por um livro". Imediatamente após esta frase, compõe no diário outra cena de Lisboa em que a analfabeta Engrácia pede a Ana de Peñalosa que escreva "uma carta de amor, de seu amante para ela". (CA, p. 84 e Cad.1.06, p. 219), o que novamente nos remete ao tema dos amores paternos que antecederam o nascimento da autora. Em todo este trecho do Caderno (8 a 21 de fevereiro), a produção do texto se faz por conjugação de elementos vivos, que se conectam dinamicamente por uma lógica não-linear ou vibratogênea (para usar o termo de Augusto Joaquim): há o plano da realidade em que a dificuldade da escrita, ao ser verbalizada, cria a escrita que, por sua vez, produz a própria escriptora; há o plano da ficcionalidade em que uma carta é escrita por uma mulher culta (Ana) a pedido de outra analfabeta (Engrácia); e há o plano da inter-relação entre o biográfico e o literário quando se pensa na pobre Amélia que teria gostado de ser amada pelo pai de Gabriela, dele merecendo uma carta de amor. Coroando estas penetrações mútuas, Ana de Peñalosa se emociona e conclui que a tal carta tem o mesmo peso afetivo de uma mensagem de Luís M. ou de São João da Cruz, respectivamente, filho adotivo e mestre da beguina.

\section{Escrita e metaescrita}

Falar da pesquisa e da composição do livro não deixa de ser uma tarefa metalinguística, no entanto observemos mais detidamente esta consciência em processo de autorreferencialidade.

Ao inaugurar um novo caderno (o $7^{\circ}$ da série 1$)$, Llansol assinala a data da escrita de Causa Amante: "Durante o tempo em que escrevo 'O nascimento de Ana de Peñalosa', começado a 6 de janeiro do mesmo ano, [...] 1979". Referir-se ao nascimento 
de um livro, também chamado "Nascimento [...]", não é casual pois Llansol está deprimida e também deseja renascer: "Nestes dias devo nascer conscientemente num mundo desconhecido e não creio sequer que esse mundo já existe para me receber" (Cad.1.07, p. 4). Desejar o próprio nascimento não é recurso metafórico, já que realmente nascemos e morremos a cada dia: "Escrevo, reconstituo, remodelo o meu Diário em face da morte. Gravemente, não tristemente. Morrer e continuar a nascer para a frente." (Cad.1.07, p. 15).

De forma lacônica, Llansol comunica em 18 de agosto de 1979 que terminou Na casa de Julho e Agosto, mostrando que a composição de um livro se faz em simultâneo a outro, num afã de proteção da "incompletude" (Cad.1.07, p. 102) que não lhe permite intervalos entre uma obra e outra. Em fevereiro do ano seguinte, ela esboça uma trilogia em que aparece o título que será atribuído ao romance em elaboração: “1. Causa Amante / 2. Numerosas Linhas / 3. Com João, última história contada por Margarida" (Cad.1.08, p. 194). Algum tempo depois (Março de 1980), no meio do desenvolvimento de dois livros (Causa Amante e Com João), a autora não sabe o que se passa consigo: "o fato de pensar livros semelhantes põe constantemente minha vida em perigo; mas também a defende do perigo. Como tudo isso se passa?" No entanto se autotranquiliza de alguma forma: "Mas eu não tenho que contar tudo / que ver tudo ao mesmo tempo" e diante da impotência de abarcar a totalidade, afirma o possível da sua potência: "Criar para o mundo o que é o núcleo (a imagem) da minha vontade" (Cad.1.08, p. 337). Na experiência radical de indecidibilidade no devir da escrita, Llansol extrai satisfação: "Sinto prazer em tentar adivinhar quem virá primeiro. Causa Amante? Com João? Numerosas Linhas? Todos são intuições do tronco principal sobre o qual reflito e exerço a minha escolha." (Cad.1.08, p. 390)

Na maioria das vezes os fragmentos são produzidos de um só jato, como espasmos intensos, intercalados com meditações de todo tipo, inclusive com as lamentações de que não consegue criar na velocidade que gostaria. Mas também há episódios que são escritos e reescritos nos Cadernos até que atinjam a forma desejada, sem contar as possíveis alterações na passagem para o datiloscrito (dossiê) e deste para a forma final editada. Exemplo do primeiro caso é o episódio sobre Margarida, cuja versão no Caderno (Cad. 1.06, pp. 268-271) se reproduz integralmente no livro (CA, pp. 37-38); e do segundo caso são as várias versões relacionadas aos episódios de Clara Serena e Luís M.

Llansol mantém um alto senso autocrítico quando está a criar e a aproveitar o material criado, como se vê nas cenas da Arrábida e dos Capuchos (transpostas para CA, 53) - “Está bem, mas o começo do texto tem que ser menos rápido" (Cad.1.08, p. 160) - pois fazer o texto equivale a desfazer o já feito, como diz 
a propósito de uma cena já composta e endereçada ao suposto livro chamado "Numerosas Linhas":

Durante esta época de fim de ano, escrevi vertiginosamente, e o que escrevi ficou guardado tudo em texto. Hoje nem quis trabalhar sobre alguns rascunhos, e tudo me pareceu falso

em relação à verdade da escrita

e transitório. Era o encontro de Margarida e Ana de Peñalosa, entre "Numerosas Linhas". Nada aproveitei, nem aproveitarei, creio, e fiz bem assim. É preciso rejeitar, podar a árvore. (Cad.1.08, p.139, 4 janeiro de 1980).

\section{A escrita das figuras}

Compondo a obra, Llansol pensa na emergência de "personagens" para além do seu controle, como vivos que tomam outros destinos: "Penso numa página desfeita de um meu livro Causa Amante. Escrevi este texto para ler no Natal, era o texto de Úrsula. Outro ser que veio ao livro. Vários seres que culminam em pontes semelhantes e se diferenciam." (Cad.1.08, p. 73)

Tal como se dá no enredo, não há controle consciente rígido na criação das figuras: “É preciso que o olhar se perca é absolutamente preciso; é preciso que eu recrie nos anos e tenha a voz dessa figura, eu" (Cad.1.07 p. 163-164). Referindo-se à criação da figura de Luís M., diz que o primeiro indício captado foi, por ser o mais reconhecível, "O que era a Língua" (Cad.1.07 p. 164). Pergunta-se sobre a natureza desses seres que lhe chegam, sem para isso obter uma resposta:

Penso em vós, todos sem exceção, todos os seres. Quem são estes seres? Como os experimentam nossos sentidos - Serão os arquétipos? E os arquétipos, o que são exatamente? Nenhuma das minhas perguntas é uma pergunta frustrada. (Cad.1.08, p. 73)

Confessa que pela primeira vez enfrenta problemas da organização, de continuar a escrever cingindo-se ao pensamento por que chama, sem ouvir as vozes que a chamam e lhe tomam o ouvido e a voz na sua consonância musical. Diante das interrogações sobre o nascimento do texto sobre Úrsula, inicia um arrazoado sobre esta figura, acabando por concluir: "Praticamente os meus textos até aqui não me davam trabalho" (Cad.1.08, p. 73).

Fazer nascer a figura de uma personagem histórica é equivalente a compor o livro em conjunto, trabalho em que se estabelece uma estreita relação entre os dois lados, com reciprocidade de influxos e interpenetrabilidade de épocas:

Falo, tantas vezes em Ana de Peñalosa, que de fato viveu, que hoje compreendo também que ela me protegeria, me seria benéfica. Saberia ela, faria parte da imensidade da sua percepção 
[?] que um dia eu me referiria a ela, a traria comigo a outro século, para juntas, contemplarmos o feito e o porfazer, o nostálgico e o errado, relatarmos em conjunto como tudo, afinal, se tinha passado com nós mesmas? Tento atingir seu rosto, suas atitudes, seu meio ambiente, sua presença trespassada pela conversa de $S$. João da Cruz. E nas diferenças e nas similitudes na experiência que também nos fez sofrer, procuro a direção para um livro que vindo de nós, representa nossa maneira de viver, somente vistos um pouco mais além. (Cad.1.07, p. 103)

\section{Publicação e crises da escrita}

Ao longo da produção do livro, Llansol experimenta crises existenciais de vários tipos, a maioria ligada a dinheiro, desentendimentos com Augusto e principalmente indiferença dos editores, como notamos no trecho abaixo em que se identifica e se distingue de Virgínia Wolf:

O nó de todas estas dificuldades, expectativas, começará a desatar-se?

E a Moraes?

E a carta de condução do Augusto?

E o empréstimo?

É a primeira vez que falo tão claramente de coisas concretas,

Mas todo este clima intrincado

me impede de escrever e,

vendo Virgínia Wolf, o seu destino, compreendo como é necessário viver e escrever e não viver sozinha com a escrita.

Viver sozinha com a escrita será uma atividade temerária. Não desejaria preparar nenhuma experiência de decadência, nem a do desprezo do corpo, nem a de forma de atividade, pois que estou multiplamente, viva.

(Cad.1.07, p. 276-277)

Pode-se observar a extensão do seu tormento com os editores quando fá-lo transbordar para a ficção no episódio em que Ana de Peñalosa assume o papel de escritora a testemunhar o processo de Inquisição de Jorge Anés. Há um momento em que interpela Engrácia para que leve as "páginas escritas, que já estão impressas e agrupadas em cadernos, para serem lidas [...]" (CA, 94). Se no romance Ana de Peñalosa se lamenta - "[...] nem sequer tenho quem me escute, [...]" (CA, 93) -, no Caderno, Llansol diz: "nem sequer tenho editor" (Cad. 1.06, p.250). No livro, Ana diz: "Se eu pudesse escrever e imprimir eu própria, pedir a Engrácia 
que pusesse os livros em circulação, livro escrito seria livro lido" (CA, 94). Tais palavras refratam o que escreve no Caderno em março do mesmo ano:

Gostaria de editar-me a mim mesma, sem obstáculos. Gostaria que não me deixassem apagar de tristeza, de um vago sentimento de inutilidade por escrever sobre uma língua que arde sobre si mesma que se devora a si mesma: mas eu não trocaria por nenhuma, que me conduzisse ao sucesso, mesmo

à riqueza,

por que

é uma espécie de paixão, de desenho de mim mesma, que me faz feliz e infeliz,

e que me oferece todo o conhecimento

limitado que possuo.

(Cad.1.06, p. 242)

Assim como Ana de Peñalosa teme pela perda dos escritos e pela desaparição de Jorge Anés em Causa Amante, Llansol se preocupa com o esquecimento dos poetas no Caderno. Inspirada num filme sobre Garcia Lorca, escreve que "Um poeta é como os outros homens simplesmente quando o matam, matam uma voz mais ele" (Cad. 1.07, p. 224), atingida por esta espécie de morte que é a do autor não-editado:

Enfim, pensei também que a Moraes [Editora] talvez se prepare para calar-se; demorar a resposta é já um sinal do livro que eu lhe enviei. Eu poderia, lentamente, contribuir para a morte da voz, aderindo a esse abandono. Mas o livro escrito faz parte da minha consciência da vida em si, que sou com ele. Preciso apenas de saber que um dia será publicado, dado a ler para ter, finalmente, uma face de homem, embora eu creia que o homem é apenas um dos seres. (Cad.1.07, p. 225)

No data do seu aniversário, 27 de novembro de 1979, a autora recebe uma boa notícia da Editora que a leva à exaltação e reafirmação do seu projeto:

Faço hoje 48 anos; a carta desejada da Moraes, chegou hoje. O livro não será posto fora do caminho, segue seu caminho para ser publicado e eu exalto-me até dores de cabeça, sentindo de novo que sou capaz de poder e de seguir a minha estrela. [...] A carta da Moraes reconduziu-me ao livro a causa amante, do esforço de encontrar-me com o meu prazer perfeito.

No entanto, em abril de 1980, a Editora Moraes volta atrás e Llansol parece desabar "como alguém que não pode exercer a sua profissão, comunicar" (Cad.1.08, p. 43) e que assim perde 
seu "trabalho" (Cad.1.08, p. 276). De modo cáustico, destila o seu desprezo pela classe dos editores:

Como me libertar (procurar não necessitar) do Editor que gera o livro, e anota na coluna do haver, a margem do lucro. Tornou-se avarento porque deve oferecer, sem margem para o erro ou um pouco de previdência da cultura, a folha de texto comestível que as massas procuram. De qualquer modo, julgo mais salutar para mim, não por o preço senão do nosso trabalho, não importa qual, na edição de um livro que para mim é uma série de combustões. (Cad.1.08, p.43)

Estas crises explicam o motivo da sua admiração por "essas pessoas da Flandres, no século XVI, Moretus, Rubens, Baltha$\operatorname{zar}^{\prime \prime 16}$ (Cad.1.07, p. 246), bem diferentes dos editores atuais que não se interessam em publicar livros que "não são fáceis e muito menos êxitos comerciais (...)", dando como exemplo A restante $V i d a$, que "tem tardado porque a Moraes queria conseguir para apresentá-lo um prefácio esclarecedor (...)" (Cad.1.08, p. 227).

De todo modo, quando a autora se vê às voltas com tais problemas procura se consolar a si mesma: "De qualquer modo, eu escrevo. É o que importa" (Cad.1.07, p. 3).

Confirmando a noção de que o escritor não escreve para ninguém em particular, mas para o futuro, Llansol não sabe "se quereria publicar os [seus] livros enquanto for viva" (Cad.1.08, p. 319), mas, em aparente contradição, ela se manifesta: “Os livros que hei de escrever serão uma longa paciência; gostaria que eles encontrassem um lugar durável fora da minha vida." (Cad.1.08, p. 73)

\section{Algumas conclusões provisórias}

A leitura dos Cadernos relativos ao período de produção de Causa Amante revelou o modo como Maria Gabriela Llansol agencia os seus pensamentos numa unidade a que ela é obrigada a chegar para levar os seus textos ao destinatário na forma final de livro, mostrando a proliferação, o caos e o cálculo que regem a composição da obra. Talvez haja aí uma "utopia": o testemunho de resistência contra as formas tradicionais da ficção e a "impostura da língua" pela exibição do seu processo de criação nos cadernos e demais manuscritos que a escritora abriu à possibilidade de consulta pouco antes de morrer.

Ao visualizarmos as várias escritas em busca da obra, percebemos melhor como ela está rizomaticamente interconectada com a biografia através de um projeto várias vezes referido

${ }_{16}$ Jean e seu filho Balthazar Moretus foram editores importantes da Antuérpia no século XVI e XVII, para os quais Rubens, pintor e pai de Clara Serena, trabalhou como ilustrador. (continuar a escrever o mesmo livro em todos) que se confirma pelo extremo cuidado em fixar a data em todos os seus escritos. Ao fazer tais anotações Llansol se apóia numa possibilidade de leitura conjugada de sua obra a partir de cortes sincrônicos de sua vida, sem esquecer evidentemente que entre os diversos cortes acontecem imensas contaminações e transformações. 
O desejo impossível da simultaneidade, bem próprio aos ficcionistas, é um tema obsedante também para Llansol: “Disse ao Augusto que queria ter tudo, no mesmo instante, mas ele disse-me que, na vida, recolhe-se tudo por fragmentos (por morceaux)" (Cad.1.08.p.175). No entanto ao datar todos os fragmentos produzidos ao longo do tempo, Llansol fixa marcos que permitem ao futuro leitor uma experiência viva de simultaneidade entre vida e obra, substituindo a narratividade fechada e circunscrita por uma textualidade espraiada e em permanente mutação. A partir de pontos fulcrais de temporalidade, que em geral os escritores abandonam em favor de um ideal de obra perfeita que esconde as costuras ou expõe no máximo uma retórica dos avessos, a abertura radical do processo constitutivo do texto em Llansol revela uma generosidade inaudita que abdica do desejo de notoriedade no âmbito das Letras em favor de um compartilhamento de segredos com o leitor. Daí provém a sua preocupação com as edições, pois a escrita precisa se processar em outras consciências para justificar a consciência de quem a disparou como um dardo em mutação.

Como se pode notar, os Cadernos manuscritos de Llansol são registros de cunho diarístico, mas não típicos diários, pois não funcionam como pura tagarelice que colmata o medo do vazio, tal como descreveu Blanchot a propósito de Amiel que em catorze mil páginas arruinou a sua vida numa escrita "fantasma de atividade intelectual". (BLANCHOT, 2005, p. 275)

\begin{abstract}
Causa Amante (1984) shows the scale mutant of text of Llansol, created in notebooks manuscripts, consolidated in "dossiers" dactiloscripts and published with arduous effort in books. First we talk about the reception of the first and second edition; after we examined the backstage of production of the text, by choosing some current topics for reflection: search for the novel, metalanguage, setting up offigures characters, difficulties of editing. Ostracized of standard narrative traditional, the novel is composed and re-composed always by a process which serves as paradigm to text signed by Maria Gabriela Llansol.
\end{abstract}

Keywords: Reception. Production. Text of Llansol 


\section{REFERENCIAS}

AGAMBEN, Giorgio. Profanações. São Paulo: Boitempo, 2007.

BARTHES, Roland. O rumor da língua. São Paulo: Martins Fontes, 2004.

BLANCHOT, Maurice. O livro por vir, São Paulo: Martins Fontes, 2005, p. 275.

La voix narrative (le "il", le neuter). In: L'entretien infini. Paris: Gallimard, 1969.

CARDOSO, Miguel Esteves. Diário de Notícias, 3 de Abril de 1984, Suplemento Revista de Livros, p. IV.

COELHO, Eduardo Prado. Jornal de Letras e Artes, Secção "A Escolha de Eduardo Prado Coelho", 14 a 20 de Fevereiro de 1984.

. Jornal de Letras e Artes, Secção "A Escolha de Eduardo Prado Coelho", 13-19 de Março de 1984, nº 88, p. 30.

. Eduardo Prado. Jornal de Letras e Artes, Secção "A Escolha de Eduardo Prado Coelho", 10 de Abril de 1984.

COLAÇO, António. “Um país onde apetece viver", Diário Popular, 25 de Outubro de 1984.

DELEUZE, Gilles e PARNET, Claire. Diálogos. Trad. José Gabriel Cunha. Lisboa: Relógio D’Água, 2004.

FOUCAULT, Michel. O que é um autor? 3. ed. s.l. : Veja / Passagens, 1992.

Estética: literatura e pintura, música e cinema. Ditos \& Escritos vol. III. Rio de Janeiro: Forense Universitária, 2001.

JOAQUIM, Augusto. Posfácio. In: LLANSOL, Maria Gabriela. Causa Amante. 2a ed. Lisboa: Relógio D’Água, 1996. pp.163-211.

JOAQUIM, Teresa Maria. “Causa Amante, a outra face”, Diário de Notícias, 24 de Maio de 1984.

LLANSOL, Maria Gabriela. O Livro das Comunidades. I da trilogia Geografia de Rebeldes, Lisboa: Afrontamento, 1977.

Causa Amante. Lisboa: Regra do Jogo, [1984]. 164 pp. Capa de João B. Coleção Artifício. Subsidiada pela associação Portuguesa dos Escritores.

. Causa Amante. 2a ed. Lisboa: Relógio D’Água, 1996. 211 pp. Posfácio de Augusto Joaquim, Coleção Ficção Portuguesa.

Entrevista a João Mendes. Jornal O Público, nº1786, 28 de janeiro de 1995.

LOURE, Regina. Jornal de Letras e Artes, 13-19 de Março de 1984, $\mathrm{n}^{\circ} 88, \mathrm{p} .12$.

MORÃO, Paula. “Um animal chamado escrita”, Expresso (Revista), Coluna "Livros", 5 de Maio 1984.

NANCY, Jean Luc. Resistência da poesia. Viseu: Edições Vendaval, s/d. 
SEIXO, Maria Alzira. "Causa Amante de Maria Gabriela Llansol”. In: A palavra do romance; Ensaio de Genologia e Análise. Lisboa, Livros Horizonte, 1986a, p. 229-232.

. "Alteridade e auto-referencialidade no romance português de hoje (A propósito das obras de J. Saramago, M. Cláudio e Maria Gabriela Llansol)". In: SEIXO, 1986b, p. 21-27.

. "Para uma tipologia do discurso ficcional (Pensando a obra de Maria Gabriela Llansol)”. In: SEIXO, 1986c, p.28-33. 